\title{
ASPEK PERSUASIF DALAM BAHASA IKLAN PARTAI POLITIK
}

\author{
Dwi Budiyanto \\ FBS Universitas Negeri Yogyakarta \\ email: matahati01@yahoo.com
}

\begin{abstract}
Abstrak
Penelitian ini bertujuan untuk mendeskripsikan aspek persuasif dalam bahasa iklan partai politik. Jenis penelitian ini adalah penelitian kualitatif melalui analisis semiotik terhadap iklan televisi partai politik Pemilu 2009. Data dikumpulkan melalui cara penyimakan dan pencatatan secara cermat. Analisis data dilakukan dengan teknik komparatif-induktif, kategorisasi, penyajian data, dan pembuatan inferensi. Hasil penelitian sebagai berikut. Aspek persuasif iklan partai politik Pemilu 2009 terdiri dari dua bentuk, yaitu (a) penyajian isi pesan: imbauan informasional, imbauan emosional, dan imbauan motivasional; dan (b) penyajian gaya pesan: hiperbola, imperatif, metaforsimile, akronimi, sinekdoke, repetisi, ironi, dan pertanyaan retoris.
\end{abstract}

Kata kunci: aspek persuasif, bahasa iklan, partai politik

\section{PERSUASIVE ASPECTS IN THE LANGUAGE OF POLITICAL PARTY ADVERTISEMENTS}

\begin{abstract}
This study aims to describe persuasive aspects in the language of political party advertisements. This was a qualitative study using a semiotic analysis of television advertisements of political parties in the 2009 general election. The data were collecting through careful reading and taking notes. The data were analyzed by means of the inductive comparative technique, categorization, data display, and inference making. The findings are as follows. The persuasive aspects in the language of advertisements of political parties in the 2009 general election consist of two forms, i.e.: (a) presentation of message contents: informational, emotional, and motivational persuasions; and (b) presentation of message styles: hyperbole, imperative, metaphor-simile, acronymy, synecdoche, repetition, irony, and rhetorical question.
\end{abstract}

Keywords: persuasive aspects, advertisement language, political parties

\section{PENDAHULUAN}

Iklan partai politik merupakan fenomena baru di Indonesia. Danial (2009: 186) menyatakan bahwa fenomena iklan politik televisi mulai menguat sejak Pemilu 2004, terutama dengan mulai dikenalnya jenis iklan kandidat. Namun, penelitian terkait dengan iklan politik, terutama iklan partai politik, ditinjau dari pemanfaatan aspekaspek linguistik yang digunakan masih sangat jarang dilakukan. Hal ini berbeda dengan iklan komersial yang telah diteliti dari banyak aspek. Padahal, iklan partai politik juga memiliki beberapa karakter yang menarik untuk diteliti. Pertama, iklan partai politik menjadi fenomenabaru dalam perpolitikan Indonesia. Ia menandai terjadinya pergeseran gaya kampanye yang menonjolkan bentuk-bentuk pengerahan massa ke arah gaya kampanye media.

Kedua, gagasan iklan politik sama dengan iklan komersial. Perbedaannya ter- 
letak pada produk yang ditawarkan dan tujuan iklan. Iklan politik tidak menjual barang, melainkan menawarkan visi, misi, dan program partai. Iklan partai politik juga tidak mengarahkan pemirsa pada perilaku membeli, melainkan mengarahkan perilaku pemirsa kepada sikap menerima partai dan memilihnya ketika pemilihan umum (Bungin, 2008: 113).

Ketiga, iklan partai politik memiliki karakter yang sama dengan iklan komersial. Jenis iklan ini pada dasarnya mengeksplorasi secara maksimal dua unsur, yaitu unsur visual yang berbentuk simbol dan unsur verbal yang berbentuk ajakan, himbauan, atau instruksi (Tinarbuko, 2009: 6). Secara verbal, bahasa yang digunakan dalam iklan lebih pendek, padat, dan lebih menonjolkan aspek bunyi atau tulisan (permainan kata-kata, bunyi, kalimat elips, dan sebagainya). Hal ini seperti diungkapkan Dyer (2009: 114) bahwa bahasa iklan secara umum bersifat informal dan menggunakan bahasa keseharian. Kalimat yang digunakan biasanya dengan konstruksi sederhana dan pendek. Pemadatan bahasa akhirnya menjadi salah satu ciri utama iklan televisi. Ia memadukan makna denotasi dan konotasi iklan sekaligus (Williamson, 2007: 133).

Komunikasi dalam iklan pada dasarnya juga sebagai salah satu upaya untuk menyampaikan ide, emosi, dan keinginan dengan format dan variasi tertentu. Oleh karena itu, pemanfaatan bahasa dalam iklan juga berkaitan dengan fungsi hakiki bahasa itu sendiri. Berkaitan dengan pemanfaatan bahasa di dalam iklan, Bungin (2008: 130) menjelaskan bahwa dalam iklan, bahasa digunakan dengan dua tujuan. Pertama, sebagai media komunikasi. Kedua, bahasa digunakan untuk menciptakan sebuah realitas. Sebagai media komunikasi, maka iklan bersifat informatif sedangkan sebagai wacana penciptaan realitas, maka iklan adalah sebuah seni untuk menciptakan dunia yang diinginkannya.
Berger, Peter L, dan Thomas Luckman (melalui Hamad, 2004: 12) menjelaskan bahwa dalam proses konstruksi realitas, bahasa menjadi unsur utama. Bahasa merupakan alat konseptualisasi dan alat narasi. Penggunaan bahasa dapat menentukan format narasi dan makna tertentu, termasuk di dalamnya adalah bentuk pencitraan yang diinginkan. Dari perspektif ini, bahasa tidak hanya mampu mencerminkan realitas, tetapi sekaligus dapat menciptakan realitas. Hanya saja, realitas yang ditampilkan dalam iklan merupakan realitas yang termanipulasi. Jean Baudrillard (Piliang, 2009: 141) menyebut fenomena ini sebagai gejala hiperealitas media (hyper-reality of media), yaitu gejala perekayasaan (dalam pengertian distorsi) makna dalam media. Akibat perekayasaan ini, sesuatu yang semu dianggap lebih nyata, dan isu lebih dipercaya daripada informasi.

Proses konstruksi realitas dalam iklan partai politik tersebut sebenarnya diarahkan untuk membangun pencitraan tertentu yang mendukung motif politik. Citra sebagai suatu konsep mengandung pengertian keseluruhan informasi tentang dunia ini yang telah diolah, diorganisasikan, dan disimpan individu (Rakhmat, 2008: 223). Dalam konteks kampanye pemilihan, citra merupakan bayangan, kesan, atau gambaran tentang suatu objek terutama partai politik, kandidat, elite politik, dan pemerintah (Pawito, 2009: 263). Dalam hal ini, objek iklan tidak ditampilkan dalam wajah yang utuh, tetapi disajikan melalui proses pencitraan yang dikonstruk lebih baik. Dalam hal ini, citra partai politik menjadi lebih mendominasi daripada kondisi partai politik itu sendiri. Keseluruhan motif tersebut dikemas melalui pemanfaatan aspek kebahasaan untuk meningkatkan daya persuasif iklan.

Dengan demikian, seperti diungkap Piliang (2003: 279), eksplorasi aspek kebahasaan dilakukan untuk memengaruhi persepsi, pemahaman, dan tingkah laku 
masyarakat terhadap produk yang ditawarkan. Dalam konteks iklan partai politik, produk yang dimaksud berupa ide, gagasan, program, dan pandangan politik. Upaya untuk memengaruhi khalayak tersebut dilakukan dengan menyentuh motif yang menggerakkan dan mendorong perilaku komunikate. Motif-motif yang dimaksud antara lain berupa imbauan rasional, imbauan emosional, imbauan takut, imbauan ganjaran, dan imbauan motivasional (Rakhmat, 2008: 298).

Secara umum, aspek persuasif dalam iklan meliputi dua hal, yaitu penyajian isi pesan dan gaya penyajian pesan. Penyajian isi pesan iklan dapat dibedakan menjadi menjadi tiga, yaitu (a) Pemanfaatan imbauan informasional (informasional appeals), yaitu isi pesan yang menekankan pada penyajian fakta, pengetahuan, dan persuasi yang bersifat logis (Efendi, 2003: 70). Kadangkala, data-data statistik dimanfaatkanuntukmemerkuat daya persuasi pesan. (b) Pemanfaatan imbauan emosional (emotional appeals), yaitu isi pesan yang berusaha menggugah emosi khalayak (Cangara, 2011: 268). (c) Pemanfaatan imbauan motivasional (motivasional appeals), yaitu isi pesan yang disusun untuk menumbuhkan pengaruh internal psikologis khalayak, sehingga mereka bersedia mengikuti pesan yang disampaikan (Cangara, 2011: 269; Rakhmat, 2008: 301).

Sementara itu, gaya penyajian pesan merupakan teknik untuk menyampaikan pesan-pesan iklan dengan memanfaatkan bahasa yang khas dan unik sehingga pesan yang disampaikan memiliki daya persuasif yang lebih baik. Salah satu kecenderungan dalam iklan yang dieksplorasi adalah pemanfaatan bahasa figuratif (figurative language). Dyer (2009: 120-124) memberikan beberapa contoh bahasa figuratif yang banyak dimanfaatkan iklan, yaitu metafor, personifikasi, metonimi, homonim, paralelisme, dan aliterasi. Tentu saja dalam konteks jenis iklan yang berbeda, bentuk eksplorasi kebahasaan yang dilakukan dapat berbeda.

\section{METODE PENELITIAN}

Penelitian ini dilaksanakan dengan pendekatan kualitatif melalui analisis semiotik. Analisis semiotik digunakan untuk mengungkap aspek persuasif dalam bahasa iklan-iklan partai politik peserta Pemilu 2009 di televisi. Analisis dilakukan terhadap petanda dan penanda semiotik yang terdapatdalam bahasa iklan partai politik.

Sumber data dalam penelitian ini adalah iklan-iklan audio-visual partai politik peserta Pemilu 2009. Iklan yang dimaksud berasal dari sembilan partai politik peserta Pemilu 2009 yang memeroleh suara signifikan yang ditandai dengan terpenuhinya ET (electoral threshold) berdasarkan pemerolehan suara hasil pemilu 2009. Pengumpulan data dilakukan melalui teknik penyimakan dan pencatatan secara cermat. Keabsahan data dilakukan dengan triangulasi data dari segi reliabilitas dan validitas. Validitas data dilakukan dengan validitas semantis, sedangkan reliabilitas data diperoleh dengan cara baca, kaji ulang (intra-rater), dan diskusi dengan teman sejawat (inter-rater). Teknik analisis data dilakukan dengan teknik komparatifinduktif, kategorisasi, penyajian data, dan pembuatan inferensi.

\section{HASIL PENELITIAN DAN PEMBA- HASAN}

Ada dua bentuk aspek persuasif, berdasarkan model penyajiannya, yang dimanfaatkan dalam iklan-iklan partai politik pada Pemilu 2009. Pertama, berdasarkan penyajian isi pesan. Kedua, berdasarkan gaya penyajian pesan. Berdasarkan penyajian isi pesannya, isi iklan disajikan dengan tiga cara, yaitu (1) pemanfaatan imbauan informasional (informational appeals), (2) pemanfaatan imbauan emosional (emotional appeals), dan pemanfaatan imbauan motivasional (motivational 
appeals). Masing-masing imbauan digunakan untuk mengemas pesan-pesan politik yang berbeda tetapi dengan tujuan yang sama, yaitu melakukan konstruksi realitas dan pencitraan politik. Sementara itu, berdasarkan gaya penyajian pesannya, isi iklan disajikan dengan memanfaatkan beberapa gaya bahasa, yaitu hiperbola, imperatif, metafor-simile, akronimi, sinekdoke, repetisi, ironi, dan pertanyaan retoris.

\section{Penyajian Isi Pesan}

Berdasarkan penyajian isi pesan, bahasa verbal iklan partai politik pada Pemilu 2009 disajikan melalui pemanfaatan imbauan informasional (informational appeals), imbauan emosional (emotional appeals), dan imbauan motivasional (motivational appeals). Dari data yang terhimpun, iklan partai politik pada Pemilu 2009 lebih memilih memanfaatkan imbauan emosional dan imbauan informasional.

Pertama, imbauan informasional. Imbauan ini dilakukan dengan memanfaatkan imbauan rasional. Jenis imbauan ini berusaha meyakinkan orang lain dengan pendekatan logis atau penyajian buktibukti (Rakhmat, 2008: 299). Beberapa iklan partai politik pada Pemilu 2009 menggunakan pendekatan logis dengan menyajikan fakta-fakta, bukti-bukti, dan data-data statistik untuk digunakan dalam menciptakan konstruk realitas.

Pengunaan data-data statistik dilakukan untuk menimbulkan kesan yang kuat, memperjelas, serta meyakinkan (Rakhmat, 2002: 29). Dengan langkah ini daya persuasi yang dirancang akan lebih kuat dan meyakinkan masyarakat. Untuk menjaga efektivitas pesan, data-data statistik disajikan lebih sederhana, tidak secara terperinci tetapi lebih cenderung untuk dilakukan pembulatan angka sehingga lebih konkret dan mudah diingat.

Beberapa partai politik memanfaatkan imbauan informasional dalam beberapa bentuk, yaitu (1) keberhasilan kinerja pemerintah, (2) performa kinerja partai politik, (3) deskripsi kondisi terdegradasi, (4) penawaran ide dan program, dan (5) kritik atas regulasi pemerintah. Hal tersebut tampak pada contoh di bawah ini.

“69\% rakyat menyatakan semakin puas atas kinerja pemerintahan Presiden $S B Y^{\prime \prime}$ (Iklan Partai Demokrat versi Penjelasan Dosen).

Tabel 1. Penyajian Isi Pesan Iklan Partai Politik 2009

\begin{tabular}{|c|c|c|c|c|}
\hline No. & Kategori & $\begin{array}{c}\text { Frekuensi } \\
\text { (Persen) }\end{array}$ & Sub-kategori & $\begin{array}{c}\text { Frekuensi } \\
\text { (Persen) }\end{array}$ \\
\hline \multirow{6}{*}{1.} & \multirow{6}{*}{$\begin{array}{l}\text { Imbauan } \\
\text { Informasional }\end{array}$} & \multirow{6}{*}{$\begin{array}{c}27 \\
(30,34)\end{array}$} & Keberhasilan Kinerja Pemerintah & $10(37,04)$ \\
\hline & & & Performa Kinerja Parpol & $6(22,22)$ \\
\hline & & & Penawaran Ide dan Program & $6(22,22)$ \\
\hline & & & Deskripsi Kondisi Terdegradasi & $3(11,11)$ \\
\hline & & & Kritik atas Regulasi Pemerintah & $2(7,41)$ \\
\hline & & & Ungkap Identitas Parpol & $19(37,25)$ \\
\hline \multirow{3}{*}{2.} & Imbauan & \multirow{3}{*}{$\begin{array}{c}51 \\
(57,30)\end{array}$} & Penguatan Aspek Performatif & $14(27,45)$ \\
\hline & Emosional & & Respon Realitas & $12(23,53)$ \\
\hline & & & Pengharapan Emosional & $6(11,76)$ \\
\hline \multirow{4}{*}{3.} & & & Reputasi Tokoh dan Parpol & $4(36,36)$ \\
\hline & Imbauan & 11 & Kesamaan Nilai dan Program & $4(36,36)$ \\
\hline & Motivasional & $(12,36)$ & Keuntungan Pribadi & $2(18,18)$ \\
\hline & & & Elektabilitas Parpol & $1(9,09)$ \\
\hline Jumlah & & $89(100)$ & & \\
\hline
\end{tabular}


Namun kini, Partai Golkar di DPR dan di pemerintahan telah menetapkan anggaran pendidikan $20 \%$ di APBN untuk meningkatkan mutu pendidikan (Iklan Partai Golkar versi Pendidikan).

Ketika sebagian orang Indonesia kehilangan lapangan kerja, pemerintah mengumumkan stimulus 71,3 triliun rupiah. Tapi siapa yang mendapat uangnya? 43 triliun adalah keringan pajak bagi orang kaya. (Iklan Partai Gerindra versi Stimulus bagi Rakyat)

Temuan tersebut memang sedikit berbeda dengan hasil penelitian Efendi (2008: 152) terhadap iklan-iklan komersial di televisi. Imbauan informasional dalam iklan-iklan komersial di televisi dilakukan dengan berbagai cara, yaitu penjelasan bahan baku, sifat dan kegunaan produk, serta hubungan sebab akibat.

Sebagaimana dijelaskan Peng \& Hackley (2009: 173-174) antara pemasaran di bidang bisnis dan politik sebenarnya sama. Perbedaannya, iklan komersial ditujukan untuk memromosikan produk, ide, serta pelayanan pada konsumen. Sementara itu, iklan politik bertujuan memromosikan kandidat, partai, alasan-alasan politik, atau agenda-agenda politik tertentu. Perbedaan inilah yang menyebabkan pemanfaatan imbauan informasional antara iklan komersial dengan iklan politik juga berbeda.

Kedua, imbauan emosional. Jenis imbauan ini menggunakan pernyataanpernyataan atau bahasa yang menyentuh emosi untuk meyakinkan pihak lain (Rakhmat, 2008: 299). Hal ini dilakukan karena pesan-pesan yang menggunakan imbauan emosional ternyata dianggap lebih berhasil daripada pesan-pesan dengan imbauan rasional.

Penelitian Efendi (2008: 154) terhadap iklan-iklan komersial di televisi menjelaskan bahwa pemanfaatan imbauan emosional ditujukan untuk menyentuh kondisi internal manusia yang diklasifikasikan dalam dua bagian; motif biologis dan motif psikologis. Motif biologi antara lain berupa kenikmatan, kesenangan, dan kemewahan. Sementara itu, motif psikologis antara lain pengalaman, petualangan, ambisi, kesetiaan, perhatian, dan sebagainya.

Temuan tersebut berbeda dengan pemanfaatan imbauan emosional dalam iklan-iklan partai politik pada Pemilu 2009. Dalam iklan partai politik, imbauan emosional dimanfaatkan sebagai ungkapan identitas partai politik, respon terhadap realitas, pengharapan emosional, dan penguatan aspek performatif. Pemanfaatan imbauan emosional dalam iklan partai politik dapat dilihat seperti kutipan di bawah ini.

"Kan partainya perempuan" (iklan

Partai Demokrat versi Testimonial)

"Senenge ibu Mega kembali" (iklan

PDIP versi Mega Kembali)

Penanda $<$ kan partainya perempuan $>$ bermaksud mengonstruksi konotasi bahwa /Partai Demokrat/ merupakan < partai yang layak didukung para perempuan>. Penanda di atas lebih menyentuh emosi perempuan. Segmentasi yang dibidik iklan adalah segmentasi perempuan. Langkah ini dilakukan sebab berdasar hasil penelitian Robinson (2010: 457) terhadap kampanye pemilu di New Zeland bahwa terdapat hubungan antara iklan politik, orientasi pasar pemilih, dan pencapaian target pemilu. Sementara itu, penanda <senenge> dimanfaatkan untuk mengungkapkan perasaan senang karena Megawati akan kembali memimpin. Sekali lagi, sentuhan emosi sangat dominan dipilih untuk memerkuat daya persuasi iklan.

Ketiga, imbauan motivasional. Dalam konteks komunikasi politik, ia merupakan teknik penyusunan pesan yang disusun untuk menumbuhkan pengaruh internal psikologis khalayak, sehingga 
mereka dapat mengikuti pesan-pesan yang disampaikan (Cangara, 2011: 269). Beberapa imbauan motif (motive appeals) yang dieksplorasi iklan-iklan partai politik Pemilu 2009, yaitu reputasi tokoh dan partai politik, kesamaan nilai dan program, elektabilitas partai politik, dan keuntungan pribadi.

Di antara empat bentuk pemanfaatan imbauan motivasional tersebut, reputasi ketokohan masih dominan menjadi pertimbangan partai politik untuk memengaruhi preferensi pemilih. Itulah sebabnya, beberapa iklan partai politik memanfaatkan imbauan motivasional untuk menunjukkan kedekatannya dengan tokoh tertentu. Dalam konteks masyarakat Indonesia dan lebih khusus lagi masyarakat yang memiliki karakter hubungan patron-client peran tokoh sangat berpengaruh dalam pengambilan keputusaan untuk memilih (Pawito, 2009: 215). Hal tersebut dapat terlihat seperti kutipan di bawah ini.

Partai Demokrat terus mendukung Presiden SBY (iklan Partai Demokrat versi Empat Tahun Pemerintahan SBY)

Pak Jusuf Kalla ngasih contoh pakai sepatu Cibaduyut (iklan Partai Golkar versi Aku Cinta Buatan Indonesia)

Berdasar kutipan di atas, Partai Demokrat mengeksplorasi penanda $<$ Presiden SBY> dan Partai Golkar mengeksplorasi penanda $<$ Pak Jusuf Kalla $>$. Hal yang sama dilakukan beberapa iklan partai politik. Secara semiotik iklan-iklan partai politik tersebut menampilkan tokoh untuk memengaruhi kondisi internal psikologis khalayak bahwa jika mereka simpatik terhadap tokoh tertentu, ketertarikan itu harus diwujudkan dengan memberikan dukungan politik. Hal ini sekaligus menunjukkan bahwa popularitas masih sangat diperhitungkan dalam dunia politik karena dianggap sebagai faktor penentu untuk memeroleh simpati masyarakat (Firmanzah, 2010: 32).

\section{Gaya Penyajian Pesan}

Berdasarkan gaya penyajian pesannya, iklan-iklan partai politik Pemilu 2009 memanfaatkan beberapa bahasa figuratif, yaitu hiperbola, imperatif, metafor-simile, akronimi, sinekdoke, repetisi, ironi, dan pertanyaan retorik. Keseluruhan bahasa figuratif tersebut dimanfaatkan untuk memerkuat daya persuasi iklan terhadap khalayak.

Hiperbola termasuk gaya bahasa yang paling dominan dimanfaatkan dalam iklan partai politik Pemilu 2009 dibandingkan gaya bahasa lainnya. Gaya bahasa ini biasanya lebih cenderung menyajikan gagasan secara berlebihan. Berdasarkan penelitian Efendi (2008: 146) terhadap iklan-iklan komersial di televisi, hiperbola banyak dimanfaatkan untuk melebih-lebihkan produk yang ditawarkan. Pernyataan yang berlebihan tersebut biasanya dihubungkan dengan kandungan bahan baku, fungsi barang, kemampuan atau keandalan, dan sebagainya. Dengan cara ini, produsen ingin membentuk kesan mendalam tentang produk yang ditawarkan, meskipun sebenarnya tidak dapat diterima logika khalayak.

Hal yang hampir sama terjadi pada iklan-iklan politik Pemilu 2009. Beberapa partai politik mengemas pesan-pesan verbal iklan mereka secara hiperbolis. Pemanfaatan gaya bahasa hiperbola dalam iklan partai politik dimanfaatkan untuk mengemukakan janji-janji politik, konsep tentang keindonesiaan, dan peran serta kinerja partai politik.

Cara yang dominan ditempuh untuk mengemas janji politik adalah dengan mengemukakan konsep-konsep abstrak yang terkesan berlebihan, tidak logis untuk dicapai dalam waktu singkat, dan tidak memiliki parameter yang jelas terkait pencapaiannya. Penanda-penanda semiotik, seperti <Insya Allah, negara kita bukan hanya tetap tegak berdiri, tetapi juga akan semakin maju dan sejahtera>(Partai 
Demokrat), <Bergabunglah bersama Partai Gerindra untuk mencapai kemerdekaan ekonomi> (Gerindra), <Mega kembali, hidup baik kembali> (PDIP), <Untuk hari esok yang lebih baik> (Partai Golkar), <Kami akan melanjutkan langkah bersama PKS untuk Indonesia Sejahtera!> (PKS), dan <Kita mampu untuk Indonesia Baru>(PAN) merupakan contoh pemanfaatan gaya bahasa hiperbola dalam iklan partai politik.

Petanda/Indonesia/ digambarkan sangat idealis dan abstrak. Dalam pandangan Newman \& Perloff (2004: 20) strategi ini disebut penggambaran akan kemungkinan situasi yang berkembang (situastional contingency). Hanya saja, dalam konteks iklan politik pada Pemilu 2009, tidak terdapat penjelasan lebih detail tentang Indonesia Raya, Indonesia Sejahtera, dan Indonesia Baru dari masing-masing partai pengiklan.

Gaya bahasa lain yang dominan dimanfaatkan adalah imperatif atau kata aksi. Penggunaan imperatif atau kata aksi merupakan hal yang umum dilakukan dalam iklan (Dyer, 2009: 111). Kata aksi merupakan pemanfaatan kata kerja dalam penyampaian pesan verbal (Efendi, 2003: 76). Dalam konteks iklan partai politik, kata-kata tersebut melekat pada kalimat imperatif yang disajikan setelah penyampaian informasi, alasan logis mengikuti pemilu, keberhasilan kinerja partai, permasalahan bangsa, dan sebagainya.

Setelah itu khalayak diajak untuk melakukan tindakan yang diharapkan partai politik. Tindakan itu dapat berupa ajakan untuk memilih, permintaan dukungan politik, ajakan untuk berjuang bersama, dan himbauan untuk melihat rekam jejak partai politik secara objektif. Namun, apapun bentuk kata aksi yang digunakan semuanya mengarah pada satu tujuan, yaitu memengaruhi preferensi politik pemilih. Penanda-penanda semiotik, seperti <Kita harus pilih orang dan partai yang benar-benar bagus. Lihatlah track recordnya $>$ (PKS), <Contreng calegnya Golkar> (Partai Golkar), <Bergabunglah bersama Gerindra agar anak-anak kita memiliki masa depan gemilang > (Partai Gerindra), $<$ Ayo bekerja dengan hati bersama Partai Hanura $>$ (Partai Hanura) merupakan beberapa contoh pemanfaatan kata imperatif dalam iklan partai politik.

Iklan-iklan partai politik Pemilu 2009 memanfaatkan metafora dan simile untuk mengemas pesan-pesan verbalnya. Metafora merupakan bentuk analogi dari dua hal yang berbeda yang dibandingkan secara implisit, yakni tersembunyi di balik ungkapan harfiahnya. Sementara itu, simile bentuk perbandingannya berbentuk eksplisit, yang ditandai oleh pemakaian unsur konstruksional semacam kata seperti, bagai, serupa, laksana, bagaikan, dan bak.

Dalam konteks iklan partai politik Pemilu 2009, metafora dan simile dimanfaatkan agar pesan-pesan verbal yang disampaikan lebih mudah dipahami. Bahkan, dalam pandangan Wyer (2002: 707) penggunaan metafor dalam iklan tidak hanya memengaruhi pemahaman terhadap informasi yang disampaikan tetapi juga memengaruhi perhatian. Pesan verbal dalam penanda semiotik $<$ Gerakan yang membuat garuda mampu terbang tinggi kembali. Suatu gerakan menuju Indonesia Raya> (Partai Gerindra), seakan-akan memperhadapkan khalayak pada keadaan Indonesia yang diibaratkan sebagai 'burung garuda'. Pesan tersebut membangun hubungan asosiatif tentang Indonesia yang diharapkan mampu maju dan berkembang seperti dulu. Pesan verbal di atas sangat metaforis, meskipun asosiasi dengan burung garuda juga sa-ngat simbolik.

Sementara itu, pemakaian gaya penyajian pesan simile tampak pada penanda <suka nggak suka pemilu itu penting. Ibarat obat bagi bangsa kita yang sakitsakitan $>$ (PKS). Iklan ini ingin menyampaikan pesan bahwa pemilihan umum 
sangat penting bagi upaya menyelesaikan permasalahan bangsa. Analogi pemilu dan obat yang disampaikan secara eksplisit jauh lebih kuat untuk dipahami, terlebih pada saat bersamaan propaganda golput pada Pemilu 2009 sangat gencar. Dalam konteks iklan partai politik Pemilu 2009, metafora dan simile berfungsi mengonkretkan dan mendramatisasikan suatu gagasan, yakni melalui pencitraan tertentu sehingga lebih mudah ditangkap, dipahami, dan dirasakan khalayak. Pesan verbal yang mudah dipahami tersebut diharapkan akan mampu memengaruhi preferensi pemilih untuk memberikan dukungannya pada partai pengiklan.

Dalam konteks iklan-iklan Pemilu 2009, PKS merupakan satu-satunya partai yang memanfaatkan gaya bahasa akronimi. Penanda-penanda semiotik, seperti $<$ Partai Kebal Sogokan $>$, <Partai Keluarga Saya $>$, <Partai Kalem dan Santun $>,<$ Partai Keberuntungan Saya $>,<$ Pasti Koruptor Sebel $>,<$ Penuh Kasih Sayang $>$, <Partai-ne Kiai lan Santri $>,<$ Partai Keren Sekali $>,<$ Peduli Kita Setiap saat $>,<$ Partai Kita Semua $>,<$ Palestina Kita Sayangi> merupakan bentukbentuk akronimi yang dimanfaatkan dalam iklan PKS. Keseluruhan pesan di atas secara sederhana mengemas pesanpesan politik yang kompleks menjadi lebih mudah dipahami. Gaya penyajian pesan ini juga mampu menjelaskan PKS dengan cara paling sederhana dan mudah. Targetnya tidak hanya pesan tersampaikan pada khalayak, tetapi nama PKS juga lebih mudah diingat.

Bentuk gaya penyajian pesan lain yang dimanfaatkan iklan-iklan partai politik pada Pemilu 2009 adalah sinekdoke. Gaya penyajian pesan ini merupakan bentuk bahasa figuratif yang mempergunakan sebagian dari sesuatu hal untuk menyatakan keseluruhan (pars pro toto) atau mempergunakan keseluruhan untuk menyatakan sebagian (totum pro parte) (Keraf, 2010: 142).
Sinekdoke totem pro parte cenderung dimanfaatkan untuk menggambarkan dampak luas dari keberhasilan pemerintah dan atau partai politik. Padahal dalam kenyataannya, dampak yang dimaksud tidak sebesar realitas media yang dikonstruksi iklan. Sementara itu, sinekdoke pars pro toto dimanfaatkan untuk (1) menunjukkan segmentasi pemilih partai politik dan (2) memperlihatkan peran besar partai politik dalam menyukseskan program-program kerakyatan. Sebuah program atau kebijakan yang sebenarnya dilakukan dengan menyertakan keterlibatan banyak pihak diklaim sebagai kontribusi salah satu partai politik saja. Dengan cara demikian, partai politik tertentu terlihat memiliki peran yang sangat besar dan menentukan. Penanda semiotik $<$ Partai Golkar di DPR dan di Pemerintahan telah menetapkan anggaran pendidikan $20 \%$ di APBN untuk meningkatkan mutu pendidikan>memperlihatkan contoh kecenderungan tersebut. Yang menetapkan anggaran APBN tentu bukan partai politik. Anggaran pendidikan 20\% di APBN diusulkan pemerintah dan ditetapkan DPR. Sementara itu, anggota DPR yang menetapkan anggaran pendidikan sebesar $20 \%$ tentu saja bukan hanya Partai Golkar, tetapi juga melibatkan partai-partai lain.

Repetisi merupakan salah satu cara yang digunakan pengiklan untuk memberikan penekanan terhadap suatu makna tertentu yang akan dikontruksi. Pengulangan tersebut dapat berupa pengulangan kata atau bagian kalimat yang dianggap penting untuk diberi penekanan. Rakhmat (2002: 29-30) menjelaskan bahwa pengulangan kata atau gagasan seringkali digunakan untuk memperkuat daya persuasi sebuah pesan. Temuan Efendi (2008: 148) dalam penelitiannya terhadap iklan-iklan komersial di televisi memperlihatkan bahwa (a) pengulangan dapat dilakukan dengan penggunaan kata yang sama untuk memulai paragraf dan (b) penyebutan nama perusahaan atau merk secara berulang. 
Pengulangan atau repetisi dalam iklan partai politik Pemilu 2009 dilakukan dengan (a) penggunaan kata kerja yang sama untuk menggambarkan keadaan beberapa kebutuhan pokok masyarakat, (b) penyebutan dan pencantuman nama tokoh dan atau partai secara berulangulang, (c) penyebutan tindakan untuk memilih partai tertentu secara berulangulang, dan (d) pengulangan slogan partai. Pengulangan-pengulangan tersebut dapat terjadi dalam satu versi iklan atau terjadi dalam beberapa versi iklan.

Penanda-penanda semiotik seperti $<$ harga BBM turun>, <minyak goreng turun $>$, <angkutan umum turun juga>, dan $<$ tariflistrik industri ya turun $>$, serta $<$ harga $B B M$ diturunkan! diturunkan! diturunkan lagi!> menggunakan kata turun atau diturunkan untuk memperkuat daya persuasi iklan. Penggunaan penanda $<$ turun $>$ yang dirangkai dengan subjek yang berbeda, seperti harga BBM, minyak goreng, angkutan umum, dan tarif listrik industri mengonstruksi makna konotatif bahwa penurunan harga terjadi pada berbagai kebutuhan pokok masyarakat. Ia menciptakan konotasi keberhasilan pemerintah dalam menjaga stabilitas harga beberapa kebutuhan pokok.

Gaya penyajian pesan yang lain ialah ironi. Gaya bahasa ini dimanfaatkan iklan partai politik Pemilu 2009, khususnya partai oposisi dan partai-partai baru, untuk menyatakan kejadian atau situasi yang tidak diharapkan. Fungsi utama gaya penyajian ini adalah untuk menyindir, mengejek, dan mengritik. Ironi yang disampaikan bukanlah suatu acuan yang ingin mengatakan sesuatu dengan makna dan maksud berlainan dari yang terkandung dalam rangkaian kata-katanya. Ironi dalam iklan partai politik disampaikan lebih jelas dan menghindari makna yang ambigu dan membingungkan. Penanda semiotik <Ketika sebagian orang Indonesia kehilangan lapangan kerja, pemerintah mengumumkan stimulus 71,3 trilyun rupiah.
43 Trilyun adalah keringanan pajak bagi orang kaya> (Partai Gerindra)merupakan contoh pemanfaatan gaya bahasa ironi dalam iklan partai politik untuk mengritik regulasi pemerintah.

Gaya bahasa yang lain ialah pertanyaan retoris. Gaya bahasa ini merupakan sarana untuk menyajikan pesan verbal dengan cara menyampaikan pertanyaan yang (sebenarnya) tidak membutuhkan jawaban, karena biasanya jawaban yang dibutuhkan sudah diketahui. Dalam konteks iklan partai politik Pemilu 2009, ditemukan dua pola pemanfaatan pertanyaan retoris. Pertanyaan retoris yang bertujuan memperkuat citra keberhasilan partai politik cenderung menyertakan jawaban setelah pertanyaan disampaikan. Jawaban tersebut diberikan untuk memperkuat penekanan pesan. Sementara itu, pertanyaan retoris yang bertujuan menyatakan kesangsian, kritik, dan ketidakpercayaan cenderung tidak menyertakan jawaban tegas dan vulgar. Dengan cara demikian, pemahaman terhadap pesan bekerja dalam pikiran khalayak secara lebih kuat.

Pesan verbal dalam penanda semiotik $<$ Soal peduli, masih perlu diingetin lagi? Soal profesional?> (PKS), dan <Akhir-akhir ini banyak yang mengaku-aku keberhasilan swasembada pangan. Padahal, tahukah Anda siapa otak di belakangnya?> (PKS) merupakan bentuk pemanfaatan pertanyaan retoris dengan tujuan menegaskan keberhasilan. Sementara itu, penanda $<$ Ketika sebagian orang Indonesia kehilangan lapangan kerja, pemerintah mengumumkan stimulus 71,3 trilyun rupiah. Tapi siapa yang mendapat uangnya?> (Partai Gerindra) merupakan bentuk pemanfaatan pertanyaan retoris dengan tujuan menyampaikan kritik.

\section{SIMPULAN}

Berdasarkan hasil penelitian dan pembahasan, dapat disimpulkan bahwa aspek persuasif dalam bahasa iklan partai politik Pemilu 2009, dari sisi penyajian 
isi pesan, lebih dominan memanfaatkan imbauan informasional dan emosional. Keduanya mendukung penguatan daya persuasif iklan sehingga seakan bersifat lebih objektif, faktual, dan menyentuh emosi khalayak. Dari sisi gaya penyajian pesan menunjukkan bahwa proses persuasif iklan cenderung hiperbolis. Realitas sosial politik ditampilkan secara berlebihan, baik tentang keberhasilan maupun keterpurukan Indonesia. Kecenderungan tersebut juga menunjukkan bahwa iklan partai politik lebih dominan menyajikan janji-janji politik yang muluk-muluk dan abstrak.

\section{UCAPAN TERIMA KASIH}

Artikel ini ditulis dengan mengolah dari sebagian hasil penelitian tesis berjudul "Konstruksi Realitas dan Pencitraan dalam Iklan Partai Politik pada Pemilu 2009: Sebuah Kajian Semiotik." Ucapan terima kasih disampaikan kepada Prof. Dr. Burhan Nurgiyantoro selaku dosen pembimbing. Ucapan terima kasih juga disampaikan kepada semua pihak yang telah banyak memberikan bantuan, saran, dan masukan dalam penelitian ini.

\section{DAFTAR PUSTAKA}

Bungin, B. 2008. Konstruksi Sosial Media Massa. Jakarta: Kencana Prenada Media Group.

Cangara, H. 2011. Komunikasi Politik: Konsep, Teori, dan Strategi. Jakarta: Rajawali Press.

Danial, A. 2009. Iklan Politik TV: Modernisasi Kampanye Politik Pasca Orde Baru. Yogyakarta: Pustaka Pelajar.

Dyer, Gillian. 2009. Advertising as Communication. London: The Taylor \& Francis e-Library.

Efendi, A. 2008. Bahasa dan Pembentukan Citra dalam Komunikasi Periklanan di Televisi. Purwokerto: Komunika, volume 2, Nomor 2, Juli-Desember, 140-160.

Efendi, A.2003. Aspek Retorik Bahasa Iklan di Televisi. Yogyakarta: Litera, volume
II, No.1, Januari, 67-79.

Firmanzah. 2010. Persaingan, Legitimas Kekuasaan, dan Marketing Politik: Pembelajaran Politik Pemilu 2009. Jakarta: Yayasan Obor Indonesia.

Hamad. 2004. Konstruksi Realitas Politik dalam Media Massa: Sebuah Studi Critical Discourse Analysis terhadap Berita-berita Politik. Jakarta: Granit.

Keraf, G. 2010. Diksi dan Gaya Bahasa. Jakarta: Gramedia Pustaka Utama.

Newman, B.I. \& Perloff, R.M. 2004. "Political Marketing: Theory, Research, and Applications" dalam Lynda Lee Kaid (ed.), Handbook of political Communication Research. Mahwah, New Jersey: Lawrence Erlbaum Associates Publishers.

Pawito. 2009. Komunikasi Politik: Media Massa dan Kampanye Pemilihan. Yogyakarta: Jalasutra.

Piliang, Y.A. 2003. Hipersemiotika: Tafsir Cultural Studies atas Matinya Makna. Yogyakarta: Jalasutra.

Piliang, Y.A. 2009. Postrealitas: Realitas Kebudayaan dalam Era Postmetafisika. Yogyakarta: Jalasutra.

Rakhmat, J. 2008. Psikologi Komunikasi. Bandung: Rosda Karya.

Rakhmat, J. 2002. Retorika Modern. Bandung: Rosda Karya.

Robinson, C. 2010. "Political Advertising and the Demonstration of Market Orientation". European Journal of Marketing vol. 44 No. 3/4, 451-459. Diunduh dari www.emeraldinsight.com/0309-0566. htm.

Tinarbuko, S. 2009. Iklan Politik dalam Realitas Media. Yogyakarta: Jalasutra.

Wyer, R.S. (2002. "Language and Advertising Effectiveness: Mediating Influences of Comprehension and Cognitive Elaboration". Psychology \& Marketing, Jul/Aug 2002, 693-712. Diunduh dari www.proquest.com.

Williamson, J. 2007. Decoding Advertisements. Yogyakarta: Jalasutra. 